\title{
Effects of Cold Plasma on Food Quality: A Review
}

\author{
Shashi K. Pankaj (D), Zifan Wan and Kevin M. Keener* \\ Center for Crops Utilization Research, Iowa State University, Ames, IA 50011, USA; \\ shashiskp143@gmail.com (S.K.P.); zwan@iastate.edu (Z.W.) \\ * Correspondence: kkeener@iastate.edu; Tel.: +1-515-294-0160
}

Received: 7 November 2017; Accepted: 18 December 2017; Published: 1 January 2018

\begin{abstract}
Cold plasma (CP) technology has proven very effective as an alternative tool for food decontamination and shelf-life extension. The impact of $\mathrm{CP}$ on food quality is very crucial for its acceptance as an alternative food processing technology. Due to the non-thermal nature, $\mathrm{CP}$ treatments have shown no or minimal impacts on the physical, chemical, nutritional and sensory attributes of various products. This review also discusses the negative impacts and limitations posed by $\mathrm{CP}$ technology for food products. The limited studies on interactions of $\mathrm{CP}$ species with food components at the molecular level offers future research opportunities. It also highlights the need for optimization studies to mitigate the negative impacts on visual, chemical, nutritional and functional properties of food products. The design versatility, non-thermal, economical and environmentally friendly nature of $\mathrm{CP}$ offers unique advantages over traditional processing technologies. However, $\mathrm{CP}$ processing is still in its nascent form and needs further research to reach its potential.
\end{abstract}

Keywords: cold plasma; food quality; physical quality; chemical quality

\section{Introduction}

Over the past decade, cold plasma $(\mathrm{CP})$ has gained significant interest for use as a non-thermal technology for food processing. The novelty of this technology lies with its non-thermal, economical, versatile and environmentally friendly nature. The applications of $\mathrm{CP}$ for food industries have been demonstrated for food decontamination [1], enzyme inactivation [2], toxin removal [3], food packaging modifications [4] and waste water treatment [5]. Particularly for food processing, CP has been shown to be effective against major food-borne pathogenic microorganisms such as Escherichia coli [6], Salmonella typhimurium [7], Staphylococcus aureus [8], and Listeria monocytogenes [9].

Quality, both in terms of objective product characteristics and subjective consumer perception, is an essential factor for the success of any food product [10]. Thermal processing of food has been in use for more than two centuries and is still the major food processing technique used in the food industries [11]. The use of severe heat leads to undesirable effects such as change in color, texture, loss of nutrients etc., motivating researchers to explore non-thermal alternatives for food processing. $\mathrm{CP}$ is one of the non-thermal technologies which has shown significant potential in this regard. $\mathrm{CP}^{\prime} \mathrm{s}$ inactivation of pathogenic and spoilage microorganisms could result in minimally processed, safe food products with extended shelf-life. However, most of the published research has been focused on microbial decontamination, with limited studies on the impact of $\mathrm{CP}$ processing on quality attributes.

The aim of this review is to provide a brief description of the $\mathrm{CP}$ technology and plasma processing for food industries and analyze the impact of $\mathrm{CP}$ processing on the quality attributes of various food products.

\section{Plasma Physics and Sources}

Plasma is a quasi-neutral ionized gas state composed of ions, free electrons, atoms and molecules in their fundamental or excited states with a net neutral charge [12]. Based on the thermal equilibrium, plasma can be 
classified as thermal and low-temperature plasma. In thermal plasma, all species exist in a thermodynamic equilibrium (e.g., arc plasma; electron temperature $\approx$ heavier species temperature $\approx 10,000 \mathrm{~K}$ ) whereas, in the other class, the temperatures of all species are the same in localized areas in the plasma. Low temperature plasma can be further subdivided into thermal plasma (quasi-equilibrium plasma), which are in a local thermal equilibrium state, and non-thermal plasma (non-equilibrium plasma), where species are in thermal non-equilibrium (e.g., glow discharges; electron temperature $\approx 10,000-100,000 \mathrm{~K}$, heavier species temperature $\approx 300-1000 \mathrm{~K})$ [2]. The non-thermal plasma, where electrons and heavier species are in thermal non-equilibrium, is referred to as cold plasma in this review. Depending on the pressure conditions, plasma can also be classified as high-pressure, atmospheric pressure and low-pressure plasma. In atmospheric pressure plasma, plasma is generated at the normal atmospheric pressure, eliminating the need for cost-intensive reaction chambers to maintain pressure.

Plasma can be generated using any kind of energy which can ionize the gases, such as electrical, thermal, optical (UV light), radioactive (gamma radiation) and X-ray electromagnetic radiation. However, electric or electromagnetic fields are widely used for $\mathrm{CP}$ generation [13]. The versatility of CP generation sources offers unique designs which are compatible with current food industry equipment. With regards to food processing, dielectric barrier discharge and jet plasma are most commonly used (Figure 1). Dielectric barrier discharge (DBD) devices consist of two metal electrodes, where at least one of these electrodes is covered with a dielectric barrier. Dielectric barriers act as a stabilizing material, avoiding any arc transition, and help in creating a large number of micro-discharges for homogeneous treatments. Plasma jet devices consist of two concentric electrodes, where the inner electrode is typically connected to a radio frequency power at high frequency causing ionization of the working gas, which exits the nozzle and gives a 'jet-like' appearance. Further details of these systems are available elsewhere [14-16].

(a)

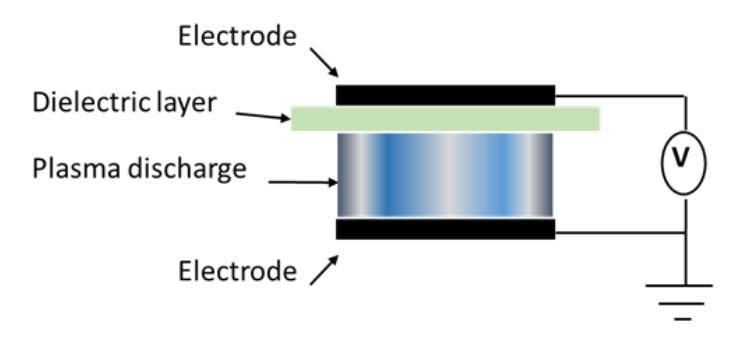

(b)

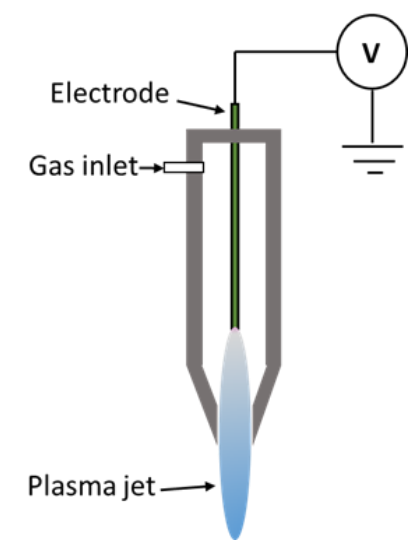

Figure 1. Schematic diagram of (a) dielectric barrier discharge; (b) plasma jet system. Adapted from [13].

However, at this point, it is worth mentioning the 'in-package' plasma mode of processing, which has demonstrated huge potential for the food processing industry [2]. In this mode, packaged food is placed between the electrodes to ionize the headspace gas to generate reactive species. The advantages of this mode of processing are easy scalability into a continuous system, enhanced antimicrobial efficacy and prevention of cross-contamination.

From a food processing perspective, plasma source, electrode design, pressure, voltage, treatment time, distance between electrodes and reactive gas all play important roles in determining the gas speciation, reactive species concentration, discharge characteristics and overall efficiency of the process. It is important to mention that the differences in various systems also present a huge challenge for researchers to compare and interpret the published results across different experimental setups. 


\section{Physical Quality}

$\mathrm{CP}$ is generally considered as a tool for surface treatments. In fact, $\mathrm{CP}$ has been used by the polymer and packaging industries for decades for surface modification and functionalization of polymers [17]. However, during processing of food, food products might be placed in strong electric field and are subjected to numerous reactive gas species that could affect physical quality attributes such as color and texture, which will be discussed in the next section. A summary of effects of $\mathrm{CP}$ on food products has been presented in Table 1. 
Table 1. Summary of effects of cold plasma processing on quality of food products.

\begin{tabular}{|c|c|c|c|c|}
\hline Sample & Plasma & Quality Observation & Microbial Observation & References \\
\hline Orange Juice & $\begin{array}{l}\text { DBD, Air } / \mathrm{MA} 65\left(65 \% \mathrm{O}_{2}\right. \\
\left.30 \% \mathrm{CO}_{2}, 5 \% \mathrm{~N}_{2}\right), 90 \mathrm{kV} \\
30-120 \mathrm{~s}\end{array}$ & $\begin{array}{l}\text { - } \\
\text { - } \quad \text { Vit.C is reduced by } 22 \% \text { in air } \\
\text { - } \\
\text { PME activity reduced by } 74 \% \text { in air and } 82 \% \\
\text { in MA65 } \\
\text { - Maximum total color difference is less } \\
\text { than } 1.2\end{array}$ & $\begin{array}{l}\text { - Up to } 5 \log _{10} \text { reduction of } \\
\text { Salmonella enterica }\end{array}$ & [18] \\
\hline Prebiotic orange juice & $\mathrm{DBD}, 70 \mathrm{kV}(50 \mathrm{~Hz}), 15-60 \mathrm{~s}$ & $\begin{array}{l}\text { - } \\
\text { - } \\
\text { Decrease in } \mathrm{pH} \\
\text { Increase in } \mathrm{L}^{*} \text { value and slight reduction in } \\
\text { chroma and hue angle } \\
\text { Decrease in total phenolic content and } \\
\text { antioxidant capacity in some cases }\end{array}$ & NA & [19] \\
\hline Cashew apple juice & $\begin{array}{l}\mathrm{PE}-100,80 \mathrm{kHz}, \mathrm{N}_{2} \\
10-50 \mathrm{~mL} / \mathrm{min}, 5-15 \mathrm{~min}, \\
30 \mathrm{kPa}\end{array}$ & $\begin{array}{l}\text { - } \\
\text { - } \\
\text { Increase in sucrose content while glucose and } \\
\text { fructose contents decreased } \\
\text { - } \quad \text { Longer treatment promoted higher } \\
\text { polyhphenol and total flavonoid content }\end{array}$ & NA & [20] \\
\hline White grape juice & $\begin{array}{l}\mathrm{DBD}, 60 \mathrm{~Hz}, 80 \mathrm{kV} \text {, } \\
1-4 \mathrm{~min} \text {, air }\end{array}$ & $\begin{array}{l}\text { - No significant change in } \mathrm{pH} \text {, acidity and } \\
\text { electrical conductivity of the juice } \\
\text { - An increase in non-enzymatic browning with } \\
\text { minimal total color difference } \\
\text { - } \quad \text { Decrease in total phenolics, total flavonoids, } \\
\text { DPPH free radicals scavenging and } \\
\text { antioxidant capacity } \\
\text { - An increase in total flavonols content }\end{array}$ & $\begin{array}{l}\text { - } 7.4 \log _{10} \mathrm{CFU} / \mathrm{mL} \text { reduction in } \\
\text { Saccharomyces cerevisiae at } 80 \mathrm{kV} \text { for } \\
4 \mathrm{~min}\end{array}$ & [21] \\
\hline
\end{tabular}


Table 1. Cont

\begin{tabular}{|c|c|c|c|c|}
\hline Sample & Plasma & Quality Observation & Microbial Observation & References \\
\hline Pomegranate juice & $\begin{array}{l}\text { Plasma jet, } 25 \mathrm{kHz}, \mathrm{Ar}, \\
0.75-1.25 \mathrm{dm}^{3} / \mathrm{min}, 3-7 \mathrm{~min}\end{array}$ & $\begin{array}{l}\text { - Increase in total anthocyanin content } \\
\text { - } \quad \text { No visual differences in color }\end{array}$ & NA & [22] \\
\hline Radish sprouts & $\begin{array}{l}\text { Microwave plasma, } \\
2.45 \mathrm{GHz}, 900 \mathrm{~W}, 669 \mathrm{~Pa} \text {, } \\
1-20 \mathrm{~min}, \mathrm{~N}_{2}, 1 \mathrm{~L} / \mathrm{min}\end{array}$ & $\begin{array}{l}\text { - No change in color, water activity, ascorbic } \\
\text { acid concentration and antioxidant activity } \\
\text { - Lower moisture content during storage }\end{array}$ & $\begin{array}{l}\text { - } \quad 2.6 \log _{10} \text { reduction in } \\
\text { Salmonella typhimurium } \\
\text { - } \quad .8 \log _{10} \text { reduction in total } \\
\text { mesophilic aerobes }\end{array}$ & [23] \\
\hline Blueberry & $\begin{array}{l}\mathrm{DBD}, 50 \mathrm{~Hz}, 60-80 \mathrm{kV} \text {, } \\
0-5 \text { min, air }\end{array}$ & $\begin{array}{l}\text { - } \quad \begin{array}{l}\text { Decrease in firmness, total phenol, flavonoid } \\
\text { and anthocyanin on extended cold plasma } \\
\text { treatment at the higher voltage level }\end{array} \\
\text { - } \quad \text { Significant increase in total soluble solid } \\
\text { - No significant change in acidity and color } \\
\text { (except fruit darkening at } 80 \mathrm{kv} \text { for } 5 \mathrm{~min} \text { ) }\end{array}$ & NA & [24] \\
\hline Blueberry & $\begin{array}{l}\text { Plasma jet, } 47 \mathrm{kHz}, 549 \mathrm{~W}, \\
\text { air, } 4-7 \mathrm{cubic} \text { feet } / \mathrm{min} \text {, } \\
7.5 \mathrm{~cm}, 0-120 \mathrm{~s}\end{array}$ & $\begin{array}{l}\text { - Significant reductions in firmness, color and } \\
\text { anthocyanins at higher treatment times }\end{array}$ & $\begin{array}{l}\text { - Upto } 2 \log _{10} \text { reduction in total aerobic } \\
\text { plate count }\end{array}$ & [25] \\
\hline Strawberry & $\begin{array}{l}\mathrm{DBD}, 60 \mathrm{kV}, 50 \mathrm{~Hz} \text {, air, } \\
5 \mathrm{~min} \text {, indirect exposure }\end{array}$ & $\begin{array}{l}\text { - No significant change in color, firmness and } \\
\text { respiration rate }\end{array}$ & $\begin{array}{l}\text { - } \quad 2 \log _{10} \text { reduction in background } \\
\text { microflora (aerobic mesophilic } \\
\text { bacteria, yeast and mould) }\end{array}$ & [26] \\
\hline Strawberry & $\begin{array}{l}\mathrm{DBD}, 60 \mathrm{kV}, 50 \mathrm{~Hz}, 65 \% \mathrm{O}_{2}+ \\
16 \% \mathrm{~N}_{2}+19 \% \mathrm{CO}_{2} \text { and } 90 \% \\
\mathrm{~N}_{2}+10 \% \mathrm{O}_{2}, 5 \mathrm{~min}, \\
\text { indirect exposure }\end{array}$ & $\begin{array}{l}\text { - } \quad \text { Strawberries in high oxygen mixture showed } \\
\text { higher firmness with similar respiration rates } \\
\text { - } \quad \text { Some changes } \mathrm{L}^{*} \text { and } \mathrm{a}^{*} \text { values } \\
\text { were observed }\end{array}$ & $\begin{array}{l}\text { - } \quad \text { 3.0 } \log _{10} \text { reduction in microbes in } \\
\text { both gas mixtures }\end{array}$ & [27] \\
\hline
\end{tabular}


Table 1. Cont.

\begin{tabular}{|c|c|c|c|c|}
\hline Sample & Plasma & Quality Observation & Microbial Observation & References \\
\hline Mandarins & $\begin{array}{l}\text { Microwave plasma, } \\
2.45 \mathrm{GHz}, 900 \mathrm{~W}, 1 \mathrm{~L} / \mathrm{min}, \\
0.7 \mathrm{kPa}, \mathrm{N}_{2}, \mathrm{He}, \mathrm{N}_{2}+\mathrm{O}_{2} \\
(4: 1), 10 \mathrm{~min}\end{array}$ & $\begin{array}{l}\text { - Increased total phenolic content and } \\
\text { antioxidant activity } \\
\text { No significant change in } \mathrm{CO}_{2} \text { generation, } \\
\text { weight loss, soluble solids, acidity, } \mathrm{pH}, \\
\text { ascorbic acid and color }\end{array}$ & $\begin{array}{l}\text { - Significant inhibition of } \\
\text { Penicillium italicum ( } 84 \% \text { reduction in } \\
\text { disease incidence) }\end{array}$ & [28] \\
\hline Kiwifruit & $\mathrm{DBD}, 15 \mathrm{kV}, 10-20 \mathrm{~min}$ & $\begin{array}{l}\text { Improved color retention and reduced } \\
\text { darkened area formation during storage } \\
\text { No significant changes in color, hardness, } \\
\text { vitamin C and antioxidant activity } \\
\text { - Longer treatment increase soluble } \\
\text { solid content } \\
\text { - } 15 \% \text { decrease in chlorophyll a on day } 0 \text { with } \\
\text { no difference on day } 4\end{array}$ & NA & [29] \\
\hline Golden delicious apples & $\begin{array}{l}\text { Gliding arc plasma, } 60 \mathrm{~Hz} \\
\text { air, } 10-40 \mathrm{~L} / \mathrm{min}, 1-3 \mathrm{~min}\end{array}$ & - No changes in color and texture & $\begin{array}{l}\text { - } \quad 3.5 \log _{10} \text { reduction in Salmonella and } \\
\text { E. coli O157:H7 reduction }\end{array}$ & [30] \\
\hline Apple (Pink Lady apples) & $\begin{array}{l}\mathrm{DBD}, 12.7 \mathrm{kHz}, 150 \mathrm{~W} \text {, air, } \\
30,120 \mathrm{~min}\end{array}$ & $\begin{array}{l}\text { - Up to } 10 \% \text { reduction of antioxidant content } \\
\text { and antioxidant capacity } \\
\text { No significant difference in total phenolic } \\
\text { content but significant decrease in total } \\
\text { phenolic index }\end{array}$ & NA & [31] \\
\hline Melon & $\begin{array}{l}\mathrm{DBD}, 15 \mathrm{kV}, 12.5 \mathrm{kHz} \text {, air, } 30 \text {, } \\
60 \mathrm{~min}\end{array}$ & $\begin{array}{l}\text { - No change in acidity, soluble solid content, } \\
\text { dry matter, color and texture } \\
\text { - } 17 \% \text { and } 7 \% \text { reduction in peroxidase and } \\
\text { PME activities respectively }\end{array}$ & $\begin{array}{l}\text { - } 3.4 \text { and } 2 \log _{10} \text { reductions in } \\
\text { mesophilic and lactic acid } \\
\text { bacteria respectively }\end{array}$ & [32] \\
\hline
\end{tabular}


Table 1. Cont

\begin{tabular}{|c|c|c|c|c|}
\hline Sample & Plasma & Quality Observation & Microbial Observation & References \\
\hline Cherry tomatoes & DBD, $100 \mathrm{kV}, 150 \mathrm{~s}$, air & $\begin{array}{l}\text { - No significant difference in color, firmness, } \\
\text { pH or total soluble solids }\end{array}$ & $\begin{array}{l}\text { - } \quad>5 \text { and } 3.5 \log _{10} \mathrm{cfu} / \text { sample } \\
\text { - } \quad \text { Up to } 3.5 \log _{10} \mathrm{cfu} / \text { sample reduction } \\
\text { on spoilage microflora (mesophiles, } \\
\text { yeast and mold) }\end{array}$ & [33] \\
\hline $\begin{array}{l}\text { Fresh fruit and vegetable } \\
\text { slices (pears, cucumbers } \\
\text { and carrots) }\end{array}$ & $\begin{array}{l}\text { Plasma micro-jet, } 30 \mathrm{~mA} \text {, } \\
500 \mathrm{~V}, 1-8 \mathrm{~min}\end{array}$ & $\begin{array}{l}\text { - Less than } 5 \% \text { moisture loss in all } \\
\text { three samples after } 8 \text { min treatment } \\
\text { - } \quad \text { Minimal change in total color difference } \\
3.6 \%, 3.2 \% \text { and } 2.8 \% \text { reduction of vitamin C } \\
\text { in cucumber, carrot and pear } \\
\text { slice, respectively }\end{array}$ & $\begin{array}{l}\text { - } 90 \%, 60 \% \text { and } 40 \% \text { Salmonella } \\
\text { inactivation in carrot, cucumber and } \\
\text { pear slice, respectively }\end{array}$ & [34] \\
\hline Red chicory & $\begin{array}{l}\mathrm{DBD}, 19.15 \mathrm{~V}, 3.15 \mathrm{~A}, 15 \mathrm{~min} \text {, } \\
\text { deionized water }\end{array}$ & $\begin{array}{l}\text { - No detrimental effects on color, freshness } \\
\text { and texture } \\
\text { - Odor and overall acceptability slightly } \\
\text { decreased during storage }\end{array}$ & $\begin{array}{l}>4 \log _{10} \mathrm{cfu} / \mathrm{cm}^{2} \text { reduction of } \\
\text { L. monocytogenes and }>5 \log _{10} \\
\text { reduction of VTEC (E. coli) }\end{array}$ & [35] \\
\hline Red chicory (radicchio) & $\begin{array}{l}\mathrm{DBD}, 15 \mathrm{kV}, 12.5 \mathrm{kHz}, \\
15-30 \mathrm{~min} \text {, air, } 1.5 \mathrm{~m} / \mathrm{s}\end{array}$ & $\begin{array}{l}\text { - No significant effects on antioxidant activity } \\
\text { and external appearance }\end{array}$ & $\begin{array}{l}\text { - } \quad 1.35 \log _{10} \mathrm{MPN} / \mathrm{cm}^{2} \text { reduction of } \\
\text { E. coli O158: } \mathrm{H} 7 \\
\text { - } 2.2 \log _{10} \mathrm{cfu} / \mathrm{cm}^{2} \text { reduction of } \\
\text { L. monocytogenes }\end{array}$ & [36] \\
\hline Romaine lettuce & $\begin{array}{l}\mathrm{DBD}, 42.6 \mathrm{kV}, 1.5 \mathrm{~A}, \\
10 \mathrm{~min} \text {, air }\end{array}$ & $\begin{array}{l}\text { - No significantly change in the surface } \\
\text { morphology, color, respiration rate and } \\
\text { weight loss }\end{array}$ & $\begin{array}{l}\text { - } 0.4-0.8 \log _{10} \mathrm{cfu} / \mathrm{g} \text { reduction of E. coli } \\
\text { O157:H7 in the leaf samples in the } 1 \text {, } \\
\text { 3, and } 5 \text { layer configurations } \\
\text { - } 1.1 \log _{10} \mathrm{cfu} / \mathrm{g} \text { reduction in bulk } \\
\text { stacking with } 7 \text { layers }\end{array}$ & [37] \\
\hline
\end{tabular}


Table 1. Cont

\begin{tabular}{|c|c|c|c|c|}
\hline Sample & Plasma & Quality Observation & Microbial Observation & References \\
\hline $\begin{array}{l}\text { Fresh produce (romaine } \\
\text { lettuce, baby carrots and } \\
\text { cocktail tomatoes) }\end{array}$ & $\begin{array}{l}\text { Atmospheric pressure cold } \\
\text { plasma, 3.95-12.83 kV, } \\
60 \mathrm{~Hz}, \mathrm{Ar}, 0.5-10 \mathrm{~min}\end{array}$ & $\begin{array}{l}\text { - No significant changes in color in } \\
\text { any samples }\end{array}$ & $\begin{array}{l}\text { - } 0.5,1.7 \text { and } 1.5 \log _{10} \text { reduction of } \\
\text { E. coli in carrot, tomato and } \\
\text { lettuce, respectively }\end{array}$ & [6] \\
\hline Lamb's lettuce & $\begin{array}{l}\text { Plasma jet, } 7.12 \mathrm{MHz}, 35 \mathrm{~W} \text {, } \\
\mathrm{Ar}, 20.000 \mathrm{sccm}, 40 \mathrm{~s}\end{array}$ & $\begin{array}{l}\text { - Strong reduction of phenolic acids } \\
\text { and flavonoids } \\
\text { - Low levels of mono- and polyphenols in leaf } \\
\text { after treatment } \\
\text { - Significant erosion of upper epidermis on } \\
\text { leaf surfaces }\end{array}$ & NA & [38] \\
\hline Unpeeled almond & $\begin{array}{l}\text { Diffuse coplanar surface } \\
\text { barrier discharge, } 20 \mathrm{kV} \text {, } \\
15 \mathrm{kHz}, \mathrm{Air}, \mathrm{O}_{2}, \mathrm{~N}_{2}, \mathrm{CO}_{2} \\
\text { and } 90 \% \mathrm{CO}_{2}+10 \% \mathrm{Ar} \\
15 \mathrm{~min}\end{array}$ & $\begin{array}{l}\text { - Plasma treatment with air and } \mathrm{N}_{2} \text { resulted in } \\
\text { a browning of the unpeeled almond } \\
\text { surface color }\end{array}$ & $\begin{array}{l}\text { - } \quad \text { 5.0, } 4.8,2.3,3.0 \text { and } 2.0 \log _{10} \\
\text { Salmonella Enteritidis PT30 reduction } \\
\text { was observed for air, } \mathrm{O}_{2}, \mathrm{CO}_{2}, \mathrm{CO}_{2}+ \\
\text { Ar and } \mathrm{N}_{2} \text { plasma respectively }\end{array}$ & [39] \\
\hline Black gram & $\begin{array}{l}\text { Radio Frequency plasma, } \\
2 \mathrm{~Pa} \text { air }(0.15 \text { mbar }) \text {, } \\
13.56 \mathrm{MHz}, 30-50 \mathrm{~W}, \\
5-15 \mathrm{~min}\end{array}$ & $\begin{array}{l}\text { - Surface etching and hydrophillization } \\
\text { of surface } \\
\text { - Decrease in hardness, cooking time, ash and } \\
\text { moisture content }\end{array}$ & NA & [40] \\
\hline Brown rice & $\begin{array}{l}\text { Radio Frequency plasma, air } \\
(0.15 \mathrm{mbar}), 13.56 \mathrm{MHz} \\
40-50 \mathrm{~W}, 5-10 \mathrm{~min}\end{array}$ & $\begin{array}{l}\text { - Decrease in cooking time, hardness, } \\
\text { chewiness, contact angle, and } \\
\text { moisture content } \\
\text { - } \quad \text { Higher degree of gelatinization } \\
\text { - Increase in water uptake, L value and } \\
\text { whiteness index }\end{array}$ & NA & [41] \\
\hline Brown rice & $\begin{array}{l}\mathrm{DBD}, 15 \mathrm{kHz}, 250 \mathrm{~W} \text {, air, } \\
5-20 \mathrm{~min}\end{array}$ & $\begin{array}{l}\text { - } \quad \text { Decrease in } \mathrm{pH} \text { and hardness } \\
\text { Increase in } \mathrm{L}^{*} \text { and decrease in } \mathrm{a}^{*} \text { and } \\
\mathrm{b}^{*} \text { values }\end{array}$ & $\begin{array}{l}\text { - } \quad \text { Microbes studies: Bacillus cereus, } \\
\text { Bacillus subtilis, E. coli O157:H7 and } \\
\text { total aerobic bacteria } \\
20 \text { min plasma treatment resulted an } \\
\text { approximately } 2.30 \log _{10} \mathrm{cfu} / \mathrm{g} \\
\text { bacterial reduction }\end{array}$ & [42] \\
\hline
\end{tabular}


Table 1. Cont.

\begin{tabular}{|c|c|c|c|c|}
\hline Sample & Plasma & Quality Observation & Microbial Observation & References \\
\hline $\begin{array}{l}\text { Grains: wheat, bean, chick } \\
\text { pea, soy bean, barley, oat, } \\
\text { rye, lentil and corn }\end{array}$ & $\begin{array}{l}\text { Low pressure cold plasma, } \\
1 \mathrm{kHz}, 20 \mathrm{kV}, 500 \mathrm{mTorr} \\
300 \mathrm{~W} \text {, air and } \mathrm{SF}_{6}, 5-20 \mathrm{~min}\end{array}$ & $\begin{array}{l}\text { - Slight change in moisture content of legume } \\
\text { and wheat } \\
\text { - No difference in water soaking, yield and } \\
\text { cooking time of legumes } \\
\text { - No change in wet gluten content, gluten } \\
\text { index and sedimentation in wheat }\end{array}$ & $\begin{array}{l}\text { - } 3 \log _{10} \text { reduction of Aspergillus spp. } \\
\text { and Penicillum spp. after } 15 \mathrm{~min} \\
\text { treatment in } \mathrm{SF}_{6}\end{array}$ & [43] \\
\hline Refined wheat flour & $\begin{array}{l}\text { DBD plasma, } 1-2.5 \mathrm{kV} \text {, } \\
50 \mathrm{~Hz}, 1-5 \mathrm{~min}\end{array}$ & $\begin{array}{l}\text { - No significant color change was observed on } \\
\text { refined wheat flour }\end{array}$ & $\begin{array}{l}\text { - } \quad \text { Significant increase in } \\
\text { Tribolium castaneum (Herbst). }\end{array}$ & [44] \\
\hline $\begin{array}{l}\text { Wheat flour } \\
\text { (soft and hard) }\end{array}$ & DBD, $60-70 \mathrm{kV}, 5-10 \mathrm{~min}$, air & $\begin{array}{l}\text { - An increase in the peak time, peak integral, } \\
\text { elastic modulus, viscous modulus, dough } \\
\text { strength and optimum mixing time } \\
\text { - No significant variation in tan } \sigma \text { for } \\
\text { both flour }\end{array}$ & NA & [45] \\
\hline Rice starch & $\begin{array}{l}\text { Radio frequency plasma, } \\
13.56 \mathrm{MHz}, 40-60 \mathrm{~W}, \\
0.15 \mathrm{mbar} \text {, air, } 5-10 \mathrm{~min}\end{array}$ & $\begin{array}{l}\text { Decrease in amylose content, turbidity, } \\
\text { gelatinization temperature, retrogradation } \\
\text { tendency, degree of starch hydrolysis and } \\
\text { pasting temperature } \\
\text { Increase in leaching of amylose, pasting, final } \\
\text { viscosities, water absorption index, solubility, } \\
\text { swelling power and syneresis }\end{array}$ & NA & [46] \\
\hline Onion powder & $\begin{array}{l}\text { Microwave plasma, } 170 \text { and } \\
250 \mathrm{~m} \mathrm{Wm}^{-2}, 2.45 \mathrm{GHz} \\
400-900 \mathrm{~W}, 10-40 \mathrm{~min}, \\
0.7 \mathrm{kPa}, \mathrm{He}, 1 \mathrm{~L} / \mathrm{min}\end{array}$ & $\begin{array}{l}\text { - No effect on color, antioxidant activity and } \\
\text { quercetin concentration }\end{array}$ & $\begin{array}{l}\text { - } 2.1 \log _{10} \text { spores } / \mathrm{cm}^{2}, 1.6 \log _{10} \\
\text { spores } / \mathrm{cm}^{2} \text { and } 1.9 \mathrm{cfu} / \mathrm{cm}^{2} \\
\text { reduction of Bacillus cereus, } \\
\text { A. brasiliensis spore, and E. coli } \\
\text { O157:H7, respectively }\end{array}$ & [47] \\
\hline
\end{tabular}


Table 1. Cont

\begin{tabular}{|c|c|c|c|c|}
\hline Sample & Plasma & Quality Observation & Microbial Observation & References \\
\hline Bacon & $\begin{array}{l}\text { Atmospheric pressure } \\
\text { plasma, } 75-125 \mathrm{~W} \text {, } \\
13.56 \mathrm{MHz}, 60 \mathrm{~s} \text { and } 90 \mathrm{~s}, \mathrm{He} \\
(10 \mathrm{lpm}) \text { and } \mathrm{He}+\mathrm{O}_{2} \\
(10 \mathrm{lpm} \text { and } 10 \mathrm{sccm})\end{array}$ & $\begin{array}{ll}\text { - } & \text { Increase in } L^{*} \text { value } \\
\text { - } & \text { No change in } \mathrm{pH} \\
& 7 \text { days of storage, plasma treated samples } \\
\text { had higher TBARS value than control }\end{array}$ & $\begin{array}{l}\text { - } \quad \text { Pathogens studied: } \\
\text { Listeria monocytogenes; Escherichia coli } \\
\text { and Salmonella typhimurium } \\
\text { - } \quad \text { Helium plasma reduce the pathogens } \\
\text { in } 1-2 \log _{10} \text { range } \\
\text { - } \quad \text { Helium/oxygen gas mixture shows a } \\
\text { reduction of pathogen in a range of } \\
2-3 \log _{10} \\
4.53 \log _{10} \mathrm{cfu} / \mathrm{g} \text { reduction in total } \\
\text { aerobic count }\end{array}$ & [48] \\
\hline Fresh and frozen pork & $\begin{array}{l}\text { Plasma jet, Air, } 20 \mathrm{kV}, \\
58 \mathrm{kHz}, 1.5 \mathrm{amp}, 0-120 \mathrm{~s}\end{array}$ & $\begin{array}{l}\text { - No significant changes in volatile basic } \\
\text { nitrogen, peroxide value and TBARS } \\
\text { - No significant impact on the sensory } \\
\text { characteristics on frozen pork } \\
\text { - Significant changes in color for both fresh } \\
\text { and frozen pork }\end{array}$ & $\begin{array}{ll}\text { - } & 1.5 \log _{10} \text { reduction of E. coli O157:H7 } \\
\text { - } & >1.0 \log _{10} \text { unit Listeria monocytogenes }\end{array}$ & [49] \\
\hline Fresh pork & $\begin{array}{l}\text { Microwave plasma, air, } \\
5-10 \mathrm{~min}, 2.45 \mathrm{GHz}, 1.2 \mathrm{~kW}, \\
20 \mathrm{slm}\end{array}$ & $\begin{array}{ll}\text { - } & \text { Increased a value and decreased b values of } \\
\text { - } & \text { pork meat } \\
\text { - } & \text { Signiference in reflectance and fluorescence. } \\
\text { Signges in } \mathrm{pH}\end{array}$ & $\begin{array}{l}\text { - Aerobic viable count remained } \\
\text { between } 10^{2} \text { and } 10^{3} \mathrm{cfu} / \mathrm{g} \text { during the } \\
\text { storage period of } 20 \text { days }\end{array}$ & [50] \\
\hline Fresh pork and beef & $\begin{array}{l}\text { Thin-layer DBD plasma, } \\
1-10 \mathrm{~min}, 100 \mathrm{~W}, \mathrm{~N}_{2}+\mathrm{O}_{2}\end{array}$ & 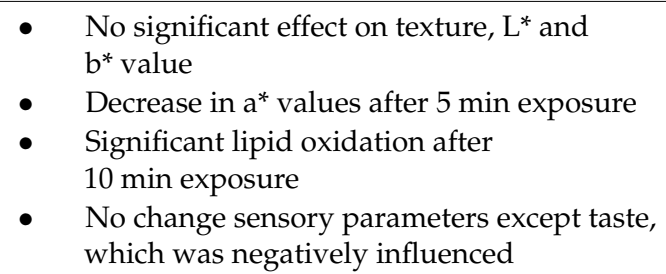 & $\begin{array}{l}\text { - Up to } 2.7 \log _{10} \mathrm{cfu} / \mathrm{g} \text { reduction of } \\
\text { Listeria monocytogenes, E. coli O157:H7 } \\
\text { and Salmonella tryphimurium in pork } \\
\text { and beef }\end{array}$ & [51] \\
\hline
\end{tabular}


Table 1. Cont

\begin{tabular}{|c|c|c|c|c|}
\hline Sample & Plasma & Quality Observation & Microbial Observation & References \\
\hline Pork Loin & $\begin{array}{l}\mathrm{DBD}, \mathrm{He} \text { or } \mathrm{He}+0.3 \% \mathrm{O}_{2} \\
5-10 \mathrm{~min}, 3 \mathrm{kV}, 30 \mathrm{kHz} \\
10 \mathrm{slm}\end{array}$ & $\begin{array}{l}\text { - Decrease in } \mathrm{pH} \text { and } \mathrm{L}^{*} \text { values with no change } \\
\text { in } \mathrm{a}^{*} \text { and } \mathrm{b}^{*} \text { values } \\
\text { - Higher lipid oxidation in Helium- } \\
\text { oxygen plasma } \\
\text { - Significant reductions in sensory quality } \\
\text { parameters (appearance, color, } \\
\text { odor, acceptability) }\end{array}$ & $\begin{array}{l}\text { - Up to } 0.55 \log _{10} \text { reduction of } E . \text { coli } \\
\text { reduction in helium and } \\
\text { helium-oxygen plasma } \\
\text { - Up to } 0.59 \log _{10} \text { reduction of } \\
\text { L. monocytogenes reduction in helium } \\
\text { and helium-oxygen plasma }\end{array}$ & [52] \\
\hline Beef jerky & $\begin{array}{l}\text { RF plasma, Ar, } 20,000 \mathrm{sccm}, \\
200 \mathrm{~W}, 0-10 \mathrm{~min}\end{array}$ & $\begin{array}{l}\text { - No significant change in fatty acid } \\
\text { composition, color and shear force }\end{array}$ & $\begin{array}{l}\text { - } \quad 1.8 \log _{10} \text { reduction in } \\
\text { Staphylococcus aureus after } \\
8 \text { min treatment }\end{array}$ & [8] \\
\hline Pork & $\begin{array}{l}\text { Pulsed plasma, } 0.8 \mathrm{MPa} \text {, } \\
20-100 \mathrm{kHz}, 1.2 \mathrm{kVA}, \mathrm{N}_{2} \\
\mathrm{He}, \mathrm{Ar}\end{array}$ & - No significant differences in color and $\mathrm{pH}$ & $\begin{array}{l}\text { - Up to } 3 \log _{10} \mathrm{cfu} / \mathrm{cm}^{2} \text { reduction of } \\
\text { psychrotroph bacteria, yeast } \\
\text { and mold }\end{array}$ & [53] \\
\hline Raw pork & $\begin{array}{l}\text { Low-pressure plasma, } \\
0-10 \mathrm{~min}, \mathrm{He}, 20 \mathrm{kPa}\end{array}$ & 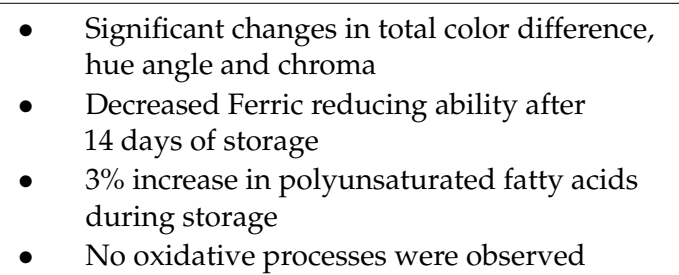 & NA & [54] \\
\hline
\end{tabular}


Table 1. Cont

\begin{tabular}{|c|c|c|c|c|}
\hline Sample & Plasma & Quality Observation & Microbial Observation & References \\
\hline Ground pork & $\begin{array}{l}\text { Plasma jet, } 7 \mathrm{kV}, 25 \mathrm{kHz}, \\
600 \mathrm{~W}, 1.67 \times 10^{-4} \mathrm{~m}^{3} / \mathrm{s} \\
60 \mathrm{~min}\end{array}$ & $\begin{array}{l}\text { - Increase in nitrite content from } 0.64 \text { to } \\
60.50 \mathrm{mg} / \mathrm{kg} \\
\text { No difference from control in nitrosyl } \\
\text { hemochrome, color, residual nitrite, texture, } \\
\text { lipid oxidation and protein oxidation } \\
\text { - Higher score in taste and overall acceptability }\end{array}$ & - No effect on total aerobic count & [55] \\
\hline Fresh mackerel fillets & $\begin{array}{l}\mathrm{DBD}, 70-80 \mathrm{kV}, 50 \mathrm{~Hz} \text {, air, } \\
1-5 \mathrm{~min}\end{array}$ & $\begin{array}{ll}\text { - } & \text { No changes in } \mathrm{pH} \text {, color (except decrease in } \\
\mathrm{L}^{*} \text { value), fat and moisture content } \\
\text { - } & \text { Higher oleic and eicosapentaenoic acid in } \\
\text { plasma treated samples } \\
\text { - } \quad \text { Significant primary oxidation (PV } \\
\text { and Dienes) } \\
\text { - } \quad \text { No significant difference in TBARS values. } \\
\text { - Decrease in } \mathrm{T}_{21} \text { (dense myofibrillar network) } \\
\text { with increased } \mathrm{T}_{22} \text { (extramyofibrillar water) }\end{array}$ & $\begin{array}{l}\text { - No significant reduction in the total } \\
\text { aerobic mesophilic count } \\
\text { Significant reduction in psychotropic } \\
\text { bacteria, lactic acid bacteria } \\
\text { and Pseudomonas }\end{array}$ & [56] \\
\hline
\end{tabular}




\subsection{Color}

Color of food products is an important attribute which has a direct effect on consumer perception and hence the success of any product. The color of food products are mostly due to presence of pigments (natural or synthetic) and chemical reactions (enzymatic or non-enzymatic). Any undesirable change in the color of food products due to processing technique will be a big obstacle for its acceptability.

Varying effects of CP treatments on the color of fresh fruits and vegetables have been reported depending on the severity of treatment conditions. Various researchers reported no significant loss of color after CP treatments of strawberry, apples, kiwifruit, cherry tomatoes, lettuce and carrots $[6,26,29,30,33]$. Some researchers reported minor changes after the $\mathrm{CP}$ treatments [27,34]. In some cases, such as blueberry, Sarangapani, O’Toole, Cullen and Bourke [24] and Lacombe, Niemira, Gurtler, Fan, Sites, Boyd and Chen [25] reported loss of color at higher treatment times. Similarly, total color difference after CP treatment of fruit juices were also found minimal and not perceptible by naked eyes [18,22]. Amini et al. [57] also observed loss in quality for saffron after increasing input voltage and addition of oxygen in the working gas. The changes in the color could be due to the partial degradation of pigments such as chlorophyll and anthocyanin, as reported in some studies [25,29]. Overall, these results demonstrate that $\mathrm{CP}$ processing has a minimal effect on the color of food products at lower treatment times. The product type (whole or cut, solid or liquid), plasma treatment parameters (input voltage, time, power, working gas) and storage conditions are some of the critical factors affecting the color.

$\mathrm{CP}$ processing was also reported to lead to certain desirable effects on the color of a few food products. Thirumdas, Saragapani, Ajinkya, Deshmukh and Annapure [41] have reported an increase in the brightness and whiteness index of brown rice after plasma treatment. In another study, Yong et al. [58] have used $\mathrm{CP}$ in the manufacturing of pork jerky without adding sodium nitrite. They used specific plasma processing parameters to achieve similar redness/color in the pork jerky without using any chemical nitrite additive. These studies extends the current area of research for development of new products with $\mathrm{CP}$ technology, which will be natural and free from chemical additives.

\subsection{Texture}

Many of the reported studies suggest the retention of texture of food products after $\mathrm{CP}$ processing. In case of fresh fruits and vegetables, no significant difference was observed after $\mathrm{CP}$ treatment of strawberry, apple, melons and cherry tomatoes $[26,30,32,33]$. However, a decrease in firmness was reported after CP treatment of blueberries [24,25]. The softening of the blueberries was attributed to the mechanical damage due to the high air-flow rates of the plasma jet and the temperature rise during the treatment. In another study on CP treatments of strawberry in modified atmosphere packaging, the firmness retention was found to be better in a high-oxygen environment $\left(65 \% \mathrm{O}_{2}+16 \% \mathrm{~N}_{2}+19 \% \mathrm{CO}_{2}\right)$ than a nitrogen-rich environment $\left(90 \% \mathrm{~N}_{2}+10 \% \mathrm{O}_{2}\right)$ [27]. This study demonstrates that plasma gas is an important factor influencing the firmness of treated products. Similar increased texture retention under high oxygen atmosphere and ozone treatments have also been reported in the literature $[59,60]$. They suggested that the enhanced firmness retention is due to the reduction in ripening rate as a stress response to high oxygen atmosphere.

CP treatment of grains and legumes resulted in a decrease in hardness and chewiness [40-42]. These groups also reported a decrease in soaking/cooking time for the plasma-treated products, which was deemed desirable for the industries. In another study on CP treatment of wheat flour, Misra, Kaur, Tiwari, Kaur, Singh and Cullen [45] reported an increase in the peak integral, elastic modulus, viscous modulus and dough strength. They also reported the effect of $\mathrm{CP}$ on the secondary structure of flour proteins. These studies highlights the potential of CP technology in processing of food ingredients for tailor-made visco-elastic properties. 


\section{Chemical Quality}

Plasma chemistry is a complex science involving numerous species in a myriad of chemical reactions occurring in different time scales [13]. For example, air plasma involves over 75 different chemical species in almost 500 chemical reactions, making it more complex to understand their interaction with food components. However, plasma reactive species are considered to be the major factor for all the observed changes in the chemical quality attributes of the treated products, which are discussed in the following sections. It is worth noting that plasma reactive species are largely dependent on the gas used for plasma generation, making this one of the most critical factors for chemical changes.

\section{1. $\mathrm{pH}$ and Acidity}

$\mathrm{pH}$ and acidity are a closely regulated quality attribute in most of the processed food products. Any drastic change could lead to an undesirable impact on the taste, texture and shelf life of the food. However, in the case of fresh fruits and vegetables, there are significant variations due to differences in cultivation practices, varietal differences, environmental parameters etc.

There are several reported studies where $\mathrm{CP}$ treatment has been shown to change the $\mathrm{pH}$ of food products $[19,42]$. The $\mathrm{pH}$ and acidity changes after plasma treatment were mostly attributed to the interaction of plasma reactive gases with the moisture present in the food products. In solid food products, plasma species reacts with the surface water, forming acidic compounds only on the surface while, in liquid products, effects were more pronounced. Oehmigen et al. [61] reported the formation of nitric acid induced by reactive nitrogen species such as $\mathrm{NO}$ as the reason for acidification in air plasma treatments. However, many researchers also reported no $\mathrm{pH}$ effect of $\mathrm{CP}$ treatments in food products with buffering capacity $[18,21]$. These results indicate that the effects of plasma on the $\mathrm{pH}$ of complex food matrices are affected by several factors such as buffering capacity, physiological activity of the living tissues, and the possibility of the liquid emanating from the damaged tissues on the surface washing off the acids on the surface [62].

\subsection{Protein and Enzymes}

The effect of $\mathrm{CP}$ on the protein and enzymes in food model food systems has been reviewed recently [2]. The effects of $\mathrm{CP}$ on various food enzymes are summarized in Table 2 . The mechanisms of protein denaturation by $\mathrm{CP}$ could be due to the interaction of plasma reactive species with amino acids [63] and secondary structure due to loss of $\alpha$-helix and $\beta$-sheet [64]. Factors like the type of protein/enzyme, type of plasma, reactive gas, processing parameters, sample volume and enzyme media play an important role on the protein denaturation and enzyme inactivation by $\mathrm{CP}$. Although the enzyme inactivation could serve as an important tool for food industries, some challenges such as optimized processing parameters, better understanding of inactivation mechanisms and protective effects of different food components [65] need to be addressed.

The effects of $\mathrm{CP}$ in muscle protein were studied in fresh mackerel, where it resulted in a decrease in immobilized water located in the protein-dense myofibrillar network [56]. Another study on wheat flour also suggested changes in protein structure due to oxidation of sulfhydryl groups and formation of disulphide bonds, affecting its structural and functional properties. 
Table 2. Effects of cold plasma on enzymes in food. Adapted from [2], with permission.

\begin{tabular}{|c|c|c|c|c|}
\hline Enzyme & Food Product & Plasma & Salient Results & Reference \\
\hline $\begin{array}{l}\text { Polyphenol } \\
\text { oxidase }\end{array}$ & Fresh-cut apples & $\begin{array}{l}\mathrm{DBD}, 15 \mathrm{kV}, \\
12.7 \mathrm{kHz} \\
10-30 \mathrm{~min}, \text { Air, } \\
1.5 \mathrm{~m} / \mathrm{s}\end{array}$ & $\begin{array}{l}\text { Linear decrease in activity with } \\
\text { treatment time. } \\
\text { Residual activity of } 88 \%, 68 \% \text { and } 42 \% \\
\text { after } 10,20 \text { and } 30 \mathrm{~min} \text { of treatment. }\end{array}$ & [66] \\
\hline $\begin{array}{l}\text { Polyphenol } \\
\text { oxidase }\end{array}$ & Fresh-cut apples & $\begin{array}{l}\mathrm{DBD}, 150 \mathrm{~W}, \\
15+15 \\
30+30 \mathrm{~min}, \mathrm{Air}, \\
1.5 \mathrm{~m} / \mathrm{s}\end{array}$ & $\begin{array}{l}\text { Noticeable reduction in superficial } \\
\text { browning but not proportional to } \\
\text { treatment time } \\
\text { Variable effects on PPO activity } \\
\text { Effect were strictly cultivar dependent }\end{array}$ & [67] \\
\hline Peroxidase & Fresh-cut melon & $\begin{array}{l}\mathrm{DBD}, 15 \mathrm{kV}, \\
12.5 \mathrm{kHz}, 15+15, \\
30+30 \mathrm{~min}, \text { Air }\end{array}$ & $\begin{array}{l}\text { Residual activity were } 91 \% \text { and } 82 \% \\
\text { after } 15+15 \text { and } 30+30 \mathrm{~min} \\
\text { treatment, respectively }\end{array}$ & [32] \\
\hline $\begin{array}{l}\text { Pectin } \\
\text { methylesterase }\end{array}$ & Fresh-cut melon & $\begin{array}{l}\text { DBD, } 15 \mathrm{kV}, \\
12.5 \mathrm{kHz}, 15+15 \\
30+30 \mathrm{~min}, \text { Air }\end{array}$ & $\begin{array}{l}15+15 \text { min treatment was ineffective } \\
\text { Residual activity was } 94 \% \text { after } \\
30+30 \text { min treatment. }\end{array}$ & [32] \\
\hline $\begin{array}{l}\text { Superoxide } \\
\text { dismutase }\end{array}$ & $\begin{array}{l}\text { Mushrooms } \\
\text { (Agaricus bisporus) }\end{array}$ & $\begin{array}{l}\text { Plasma jet, } 18 \mathrm{kV}, \\
10 \mathrm{kHz}, 98 \% \mathrm{Ar}+ \\
2 \% \mathrm{O}_{2}, 5 \mathrm{~L} / \mathrm{min}\end{array}$ & $\begin{array}{l}\text { SOD activity was higher in plasma } \\
\text { treated mushroom during storage }\end{array}$ & [68] \\
\hline
\end{tabular}

SOD: Superoxide dismutase; PPO: Polyphenol oxidase.

\subsection{Carbohydrates}

Carbohydrates play an important role in defining and maintaining the quality of different food products. CP treatment of cashew apple juice resulted in the degradation of all the reducing sugars, such as fructose and glucose and non-reducing sucrose [20]. They also reported an increase in sucrose content after long exposure to $\mathrm{CP}$, which they attributed to the degradation of the oligosaccharides with a high degree of polymerization. A similar decrease in the fructose, increase in the sucrose and degradation of oligosaccharides with a high degree of polymerization was also reported after CP treatment of prebiotic orange juice [19]. The studies suggest ozonolysis to be the main route of degradation causing the cleavage of glycoside bonds, leading to de-polymerization of the macromolecule and the oxidation of functional groups to form carbonyl and carboxyl compounds, lactones, hydroperoxides and $\mathrm{CO}_{2}[19,69]$.

The effect of $\mathrm{CP}$ on polysaccharides has been mainly focused on starch in legume and grain products. An increase in the water uptake rate in black gram was reported by Sarangapani, Devi, Thirumdas, Trimukhe, Deshmukh and Annapure [40], which they attributed to the surface etching and increase in water binding sites due to fragmentation of starch and protein by plasma reactive species. The same group also reported a decrease in cooking time of brown rice, indicating the incorporation of polar groups between the starch molecules [41]. They also reported an increase in degree of gelatinization after plasma treatment. In another study on rice starch, Thirumdas, Trimukhe, Deshmukh and Annapure [46] reported a decrease in the amylose content, gelatinization temperature, pasting temperature, retrogradation tendency and degree of hydrolysis. Overall, it could be concluded that $\mathrm{CP}$ treatment lead to de-polymerization and cross-linking of starch affecting its structural, functional and rheological properties.

\subsection{Vitamins}

The sensitivity of vitamins to different processing techniques is essential to preserve the nutritional properties of the food products. While some vitamins, such as riboflavin (B2), pyridoxine (B6) and biotin, are usually stable, others, such as Thiamin (B1) and vitamins A, C and E, are relatively labile [70]. Most of the reported studies on $\mathrm{CP}$ treatment of food products have only focused on vitamin $\mathrm{C}$ (ascorbic acid) stability. 
Most of the studies on CP treatment of whole fruits and vegetables have reported no significant reduction in ascorbic acid content after plasma treatment. Ramazzina, Berardinelli, Rizzi, Tappi, Ragni, Sacchetti and Rocculi [29], Oh, Song and Min [23] and Song et al. [71] reported no significant effect on ascorbic acid in kiwifruit, radish sprout and lettuce, respectively. However, up to $4 \%$ reduction in ascorbic acid content was observed after plasma treatment of cut fruits and vegetables [34]. The reduction in ascorbic acid was also observed after CP treatment of orange juice [18] and cashew apple juice [20]. The degradation of ascorbic acid could be attributed to the reaction with ozone and other oxidizing plasma species during the processing. Sample type (whole/cut), processing time and plasma gas were critical factor for ascorbic acid degradation. However, it is important to emphasize the need for further studies to analyze the effects of $\mathrm{CP}$ on other vitamins in the food products along with the mechanism of degradation.

\subsection{Lipids}

Lipid oxidation is a major concern for muscle foods, which could lead to undesirable changes in the color, taste, odor and shelf life. Lipid oxidation is a complex process involving free radical chain mechanisms forming fatty acyl peroxides or other oxidation products [72]. Thiobarbituric acid reactive substance (TBARS) and peroxide value (PV) are commonly employed to measure lipid oxidation. Since CP is often considered as an advanced oxidation process, it is essential to analyze its influence on the lipids present in the muscle foods.

No significant effect on lipid oxidation were observed after CP treatment in fresh and frozen pork [49], beef jerky [8] and raw pork [54]. However, Jayasena, Kim, Yong, Park, Kim, Choe and Jo [51] reported an increase in lipid oxidation in fresh pork and beef after treating it for an extended time period of $10 \mathrm{~min}$. An increase in lipid oxidation was also reported in pork loin, when it was treated with an oxygen-containing plasma gas. Recently, Albertos, Martin-Diana, Cullen, Tiwari, Ojha, Bourke, Álvarez and Rico [56] have reported that CP treatment led to a significant lipid oxidation in fresh mackerel fillets. They observed an increase in PV from 6.89 to 37.57 meq. active oxygen $/ \mathrm{kg}$ lipids and dienes from 1.42 to $5.56 \mathrm{mmol}$ of hydroperoxides $/ \mathrm{kg}$ lipid after plasma treatment at $80 \mathrm{kV}$ for $5 \mathrm{~min}$. They also observed a decrease in oleic acid (C18:1, n-9) and eicosapentaenoic acid (C20:5, n-3) after plasma treatments. Recently, Sarangapani et al. [73] have shown that cold plasma oxidation of lipids follow the Criegee mechanism. They also identified typical oxidation products in model dairy and meat fat matrices as ozonides, aldehydes (hexanal, pentenal, nonanal and nonenal) and carboxylic acids (9-oxononanoic acid, octanoic acid, nonanoic acid), along with hydroperoxides (9-and 13-hydroperoxy-octadecadienoylglycerol species). The available studies on the effects of CP on lipids in different food products are very limited. However, based on the reported studies, treatment time and plasma gas could be considered as critical factors affecting lipid oxidation.

Yepez and Keener [74] reported a novel application of CP treatment recently. They showed the potential of hydrogen plasma to be used for the manufacturing of partially hydrogenated soybean oil without any trans-fatty acid. CP technology has shown unique advantages over the current hydrogenation processes as it can be performed at room temperature, under atmospheric pressure without any catalyst. Although this approach demonstrates an alternative to the traditional catalytic hydrogenation, further research is needed to optimize the treatment process and evaluate the performance of partially hydrogenated oil made from CP.

\subsection{Antioxidant Activity}

Although antioxidant activity is not a direct quality attribute used in the food industries, it is a close indicator of various polyphenols, flavonoids and flavanols present in the food products. The antioxidant effects of phenolic compounds could be due to their redox properties, which include possible mechanisms such as free-radical scavenging activity, transition metal-chelating activity and singlet-oxygen quenching capacity [75]. The antioxidant activities in food are generally analyzed using 3-ethyl-benzothiazoline-6-sulfonic acid (ABTS) radical scavenging activity, oxygen radical absorbance 
capacity (ORAC), 2,2-diphenyl-1-picrylhydrazyl (DPPH) scavenging activity, and ferric reducing ability of plasma (FRAP) assay.

The reported results on the effects of $\mathrm{CP}$ treatment on the phenolic contents of the food products have a wide degree of variation. A decrease in the total phenols was reported in orange juice [19], white grape juice [21], and lamb's lettuce [38]. No significant effect in apples [31] but a significant increase in cashew apple juice [20] and blueberries [24] were also reported. These differences in the reported studies highlights the research needed to better understand the effects of $\mathrm{CP}$ on polyphenols at a molecular level.

No significant changes in the antioxidant capacity after CP treatment were reported in radish sprouts, kiwifruits, red chicory and onion powder $[23,29,36,47]$. Some studies have shown a reduction in antioxidant activity after $\mathrm{CP}$ treatments in apples, white grape juice, and cashew apple juice on an extended exposure [20,21,31]. Almeida, Cavalcante, Cullen, Frias, Bourke, Fernandes and Rodrigues [19] reported a reduction in the antioxidant capacity of prebiotic orange juice after direct mode of plasma treatment whereas insignificant effects were reported when treated under indirect mode. These studies show that the type of food products, plasma generation source, mode of exposure and treatment parameters are critical in controlling the effects of $\mathrm{CP}$ on the antioxidant activity of food products.

\section{Conclusions}

Cold plasma is a novel, non-thermal technology which has shown good potential for food decontamination. However, most of the research is largely focused on microbial inactivation studies, with limited emphasis on food quality. Cold plasma processing has been shown to affect the quality attributes of the food products during treatment as well as in storage. It presents a research opportunity to further explore the effects of cold plasma on the physico-chemical and sensory properties of the food products at the molecular level. The differences in the reported studies demonstrate the need for mechanistic studies to understand the interaction of plasma reactive species with food components. Optimization studies are also required to avoid the negative impacts on quality, such as accelerated lipid oxidation, loss of vitamins and sensory characteristics. The precise understanding of the mechanisms and control over the quality attributes will be required for cold plasma technology to realize its full potential at commercial scale.

Author Contributions: S.K.P., Z.W. and K.M.K. equally contributed to the background research, writing, and reviewing of this manuscript.

Conflicts of Interest: The authors declare no conflict of interest.

\section{References}

1. Misra, N.N.; Tiwari, B.K.; Raghavarao, K.S.M.S.; Cullen, P.J. Nonthermal plasma inactivation of food-borne pathogens. Food Eng. Rev. 2011, 3, 159-170. [CrossRef]

2. Misra, N.N.; Pankaj, S.K.; Segat, A.; Ishikawa, K. Cold plasma interactions with enzymes in foods and model systems. Trends Food Sci. Technol. 2016, 55, 39-47. [CrossRef]

3. Misra, N.N. The contribution of non-thermal and advanced oxidation technologies towards dissipation of pesticide residues. Trends Food Sci. Technol. 2015, 45, 229-244. [CrossRef]

4. Pankaj, S.K.; Bueno-Ferrer, C.; Misra, N.N.; Milosavljević, V.; O’Donnell, C.P.; Bourke, P.; Keener, K.M.; Cullen, P.J. Applications of cold plasma technology in food packaging. Trends Food Sci. Technol. 2014, 35, 5-17. [CrossRef]

5. Sarangapani, C.; Misra, N.N.; Milosavljevic, V.; Bourke, P.; O'Regan, F.; Cullen, P.J. Pesticide degradation in water using atmospheric air cold plasma. J. Water Process Eng. 2016, 9, 225-232. [CrossRef]

6. Bermúdez-Aguirre, D.; Wemlinger, E.; Pedrow, P.; Barbosa-Cánovas, G.; Garcia-Perez, M. Effect of atmospheric pressure cold plasma (APCP) on the inactivation of Escherichia coli in fresh produce. Food Control 2013, 34, 149-157. [CrossRef] 
7. Fernández, A.; Noriega, E.; Thompson, A. Inactivation of Salmonella enterica serovar Typhimurium on fresh produce by cold atmospheric gas plasma technology. Food Microbiol. 2013, 33, 24-29. [CrossRef] [PubMed]

8. Kim, J.-S.; Lee, E.-J.; Choi, E.H.; Kim, Y.-J. Inactivation of Staphylococcus aureus on the beef jerky by radio-frequency atmospheric pressure plasma discharge treatment. Innov. Food Sci. Emerg. Technol. 2014, 22, 124-130. [CrossRef]

9. Ziuzina, D.; Patil, S.; Cullen, P.J.; Keener, K.M.; Bourke, P. Atmospheric cold plasma inactivation of Escherichia coli, Salmonella enterica serovar Typhimurium and Listeria monocytogenes inoculated on fresh produce. Food Microbiol. 2014, 42, 109-116. [CrossRef] [PubMed]

10. Grunert, K.G. Food quality and safety: Consumer perception and demand. Eur. Rev. Agric. Econ. 2005, 32, 369-391. [CrossRef]

11. Pankaj, S.K. Thermal processing of food. In Advances in Food Biotechnology; John Wiley \& Sons Ltd.: Hoboken, NJ, USA, 2015; pp. 681-692.

12. Pankaj, S.K.; Misra, N.N.; Cullen, P.J. Kinetics of tomato peroxidase inactivation by atmospheric pressure cold plasma based on dielectric barrier discharge. Innov. Food Sci. Emerg. Technol. 2013, 19, 153-157. [CrossRef]

13. Pankaj, S.K.; Keener, K.M. Cold plasma applications in food packaging. In Reference Module in Food Science; Elsevier: Amsterdam, The Netherlands, 2017.

14. Tendero, C.; Tixier, C.; Tristant, P.; Desmaison, J.; Leprince, P. Atmospheric pressure plasmas: A review. Spectrochim. Acta Part B At. Spectrosc. 2006, 61, 2-30. [CrossRef]

15. Bárdos, L.; Baránková, H. Cold atmospheric plasma: Sources, processes, and applications. Thin Solid Films 2010, 518, 6705-6713. [CrossRef]

16. Conrads, H.; Schmidt, M. Plasma generation and plasma sources. Plasma Sources Sci. Technol. 2000, 9, 441. [CrossRef]

17. Pankaj, S.K.; Keener, K.M. Cold plasma: Background, applications and current trends. Curr. Opin. Food Sci. 2017, 16, 49-52. [CrossRef]

18. Xu, L.; Garner, A.L.; Tao, B.; Keener, K.M. Microbial inactivation and quality changes in orange juice treated by high voltage atmospheric cold plasma. Food Bioprocess Technol. 2017, 10, 1-14. [CrossRef]

19. Almeida, F.D.L.; Cavalcante, R.S.; Cullen, P.J.; Frias, J.M.; Bourke, P.; Fernandes, F.A.; Rodrigues, S. Effects of atmospheric cold plasma and ozone on prebiotic orange juice. Innov. Food Sci. Emerg. Technol. 2015, 32, 127-135. [CrossRef]

20. Rodríguez, Ó.; Gomes, W.F.; Rodrigues, S.; Fernandes, F.A. Effect of indirect cold plasma treatment on cashew apple juice (Anacardium occidentale L.). LWT-Food Sci. Technol. 2017, 84, 457-463. [CrossRef]

21. Pankaj, S.K.; Wan, Z.; Colonna, W.; Keener, K.M. Effect of high voltage atmospheric cold plasma on white grape juice quality. J. Sci. Food Agric. 2017, 97, 4016-4021. [CrossRef] [PubMed]

22. Kovačević, D.B.; Putnik, P.; Dragović-Uzelac, V.; Pedisić, S.; Jambrak, A.R.; Herceg, Z. Effects of cold atmospheric gas phase plasma on anthocyanins and color in pomegranate juice. Food Chem. 2016, 190, 317-323. [CrossRef] [PubMed]

23. Oh, Y.J.; Song, A.Y.; Min, S.C. Inhibition of Salmonella typhimurium on radish sprouts using nitrogen-cold plasma. Int. J. Food Microbiol. 2017, 249, 66-71. [CrossRef] [PubMed]

24. Sarangapani, C.; O'Toole, G.; Cullen, P.; Bourke, P. Atmospheric cold plasma dissipation efficiency of agrochemicals on blueberries. Innov. Food Sci. Emerg. Technol. 2017, 44, 235-241. [CrossRef]

25. Lacombe, A.; Niemira, B.A.; Gurtler, J.B.; Fan, X.; Sites, J.; Boyd, G.; Chen, H. Atmospheric cold plasma inactivation of aerobic microorganisms on blueberries and effects on quality attributes. Food Microbial. 2015, 46, 479-484. [CrossRef] [PubMed]

26. Misra, N.; Patil, S.; Moiseev, T.; Bourke, P.; Mosnier, J.; Keener, K.; Cullen, P. In-package atmospheric pressure cold plasma treatment of strawberries. J. Food Eng. 2014, 125, 131-138. [CrossRef]

27. Misra, N.; Moiseev, T.; Patil, S.; Pankaj, S.; Bourke, P.; Mosnier, J.; Keener, K.; Cullen, P. Cold plasma in modified atmospheres for post-harvest treatment of strawberries. Food Bioprocess Technol. 2014, 7, 3045-3054. [CrossRef]

28. Won, M.Y.; Lee, S.J.; Min, S.C. Mandarin preservation by microwave-powered cold plasma treatment. Innov. Food Sci. Emerg. Technol. 2017, 39, 25-32. [CrossRef]

29. Ramazzina, I.; Berardinelli, A.; Rizzi, F.; Tappi, S.; Ragni, L.; Sacchetti, G.; Rocculi, P. Effect of cold plasma treatment on physico-chemical parameters and antioxidant activity of minimally processed kiwifruit. Postharvest Biol. Technol. 2015, 107, 55-65. [CrossRef] 
30. Niemira, B.A.; Sites, J. Cold plasma inactivates Salmonella Stanley and Escherichia coli O157:H7 inoculated on golden delicious apples. J. Food Prot. 2008, 71, 1357-1365. [CrossRef] [PubMed]

31. Ramazzina, I.; Tappi, S.; Rocculi, P.; Sacchetti, G.; Berardinelli, A.; Marseglia, A.; Rizzi, F. Effect of cold plasma treatment on the functional properties of fresh-cut apples. J. Agric. Food Chem. 2016, 64, 8010-8018. [CrossRef] [PubMed]

32. Tappi, S.; Gozzi, G.; Vannini, L.; Berardinelli, A.; Romani, S.; Ragni, L.; Rocculi, P. Cold plasma treatment for fresh-cut melon stabilization. Innov. Food Sci. Emerg. Technol. 2016, 33, 225-233. [CrossRef]

33. Ziuzina, D.; Misra, N.; Cullen, P.; Keener, K.; Mosnier, J.; Vilaró, I.; Gaston, E.; Bourke, P. Demonstrating the potential of industrial scale in-package atmospheric cold plasma for decontamination of cherry tomatoes. Plasma Med. 2016, 6, 397-412. [CrossRef]

34. Wang, R.; Nian, W.; Wu, H.; Feng, H.; Zhang, K.; Zhang, J.; Zhu, W.; Becker, K.; Fang, J. Atmospheric-pressure cold plasma treatment of contaminated fresh fruit and vegetable slices: Inactivation and physiochemical properties evaluation. Eur. Phys. J. D 2012, 66, 1-7. [CrossRef]

35. Trevisani, M.; Berardinelli, A.; Cevoli, C.; Cecchini, M.; Ragni, L.; Pasquali, F. Effects of sanitizing treatments with atmospheric cold plasma, sds and lactic acid on verotoxin-producing Escherichia coli and Listeria monocytogenes in red chicory (radicchio). Food Control 2017, 78, 138-143. [CrossRef]

36. Pasquali, F.; Stratakos, A.C.; Koidis, A.; Berardinelli, A.; Cevoli, C.; Ragni, L.; Mancusi, R.; Manfreda, G.; Trevisani, M. Atmospheric cold plasma process for vegetable leaf decontamination: A feasibility study on radicchio (red chicory, Cichorium intybus L.). Food Control 2016, 60, 552-559. [CrossRef]

37. Min, S.C.; Roh, S.H.; Niemira, B.A.; Boyd, G.; Sites, J.E.; Uknalis, J.; Fan, X. In-package inhibition of E. coli O157:H7 on bulk romaine lettuce using cold plasma. Food Microbiol. 2017, 65, 1-6. [CrossRef] [PubMed]

38. Grzegorzewski, F.; Ehlbeck, J.; Schlüter, O.; Kroh, L.W.; Rohn, S. Treating lamb's lettuce with a cold plasma-Influence of atmospheric pressure ar plasma immanent species on the phenolic profile of Valerianella locusta. LWT-Food Sci. Technol. 2011, 44, 2285-2289. [CrossRef]

39. Hertwig, C.; Leslie, A.; Meneses, N.; Reineke, K.; Rauh, C.; Schlüter, O. Inactivation of Salmonella enteritidis PT30 on the surface of unpeeled almonds by cold plasma. Innov. Food Sci. Emerg. Technol. 2017, 44, $242-248$. [CrossRef]

40. Sarangapani, C.; Devi, R.Y.; Thirumdas, R.; Trimukhe, A.M.; Deshmukh, R.R.; Annapure, U.S. Physico-chemical properties of low-pressure plasma treated black gram. LWT-Food Sci. Technol. 2017, 79, 102-110. [CrossRef]

41. Thirumdas, R.; Saragapani, C.; Ajinkya, M.; Deshmukh, R.; Annapure, U. Influence of low pressure cold plasma on cooking and textural properties of brown rice. Innov. Food Sci. Emerg. Technol. 2016, 37, 53-60. [CrossRef]

42. Lee, K.H.; Kim, H.-J.; Woo, K.S.; Jo, C.; Kim, J.-K.; Kim, S.H.; Park, H.Y.; Oh, S.-K.; Kim, W.H. Evaluation of cold plasma treatments for improved microbial and physicochemical qualities of brown rice. LWT-Food Sci. Technol. 2016, 73, 442-447. [CrossRef]

43. Selcuk, M.; Oksuz, L.; Basaran, P. Decontamination of grains and legumes infected with Aspergillus spp. and Penicillum spp. By cold plasma treatment. Bioresour. Technol. 2008, 99, 5104-5109. [CrossRef] [PubMed]

44. Mahendran, R. Effect of cold plasma on mortality of Tribolium castaneum on refined wheat flour. In Proceedings of the 10th International Conference on Controlled Atmosphere and Fumigation in Stored Products (CAF 2016), Winnipeg, MB, Canada, 7-11 November 2016; pp. 142-146.

45. Misra, N.; Kaur, S.; Tiwari, B.K.; Kaur, A.; Singh, N.; Cullen, P. Atmospheric pressure cold plasma (ACP) treatment of wheat flour. Food Hydrocoll. 2015, 44, 115-121. [CrossRef]

46. Thirumdas, R.; Trimukhe, A.; Deshmukh, R.; Annapure, U. Functional and rheological properties of cold plasma treated rice starch. Carbohydr. Polym. 2017, 157, 1723-1731. [CrossRef] [PubMed]

47. Kim, J.E.; Oh, Y.J.; Won, M.Y.; Lee, K.-S.; Min, S.C. Microbial decontamination of onion powder using microwave-powered cold plasma treatments. Food Microbial. 2017, 62, 112-123. [CrossRef] [PubMed]

48. Kim, B.; Yun, H.; Jung, S.; Jung, Y.; Jung, H.; Choe, W.; Jo, C. Effect of atmospheric pressure plasma on inactivation of pathogens inoculated onto bacon using two different gas compositions. Food Microbiol. 2011, 28, 9-13. [CrossRef] [PubMed]

49. Choi, S.; Puligundla, P.; Mok, C. Corona discharge plasma jet for inactivation of Escherichia coli O157:H7 and listeria monocytogenes on inoculated pork and its impact on meat quality attributes. Ann. Microbiol. 2016, 66, 685-694. [CrossRef] 
50. Fröhling, A.; Durek, J.; Schnabel, U.; Ehlbeck, J.; Bolling, J.; Schlüter, O. Indirect plasma treatment of fresh pork: Decontamination efficiency and effects on quality attributes. Innov. Food Sci. Emerg. Technol. 2012, 16, 381-390. [CrossRef]

51. Jayasena, D.D.; Kim, H.J.; Yong, H.I.; Park, S.; Kim, K.; Choe, W.; Jo, C. Flexible thin-layer dielectric barrier discharge plasma treatment of pork butt and beef loin: Effects on pathogen inactivation and meat-quality attributes. Food Microbiol. 2015, 46, 51-57. [CrossRef] [PubMed]

52. Kim, H.-J.; Yong, H.I.; Park, S.; Choe, W.; Jo, C. Effects of dielectric barrier discharge plasma on pathogen inactivation and the physicochemical and sensory characteristics of pork loin. Curr. Appl. Phys. 2013, 13, 1420-1425. [CrossRef]

53. Ulbin-Figlewicz, N.; Brychcy, E.; Jarmoluk, A. Effect of low-pressure cold plasma on surface microflora of meat and quality attributes. J. Food Sci. Technol. 2015, 52, 1228-1232. [CrossRef] [PubMed]

54. Ulbin-Figlewicz, N.; Jarmoluk, A. Effect of low-pressure plasma treatment on the color and oxidative stability of raw pork during refrigerated storage. Food Sci. Technol. Int. 2016, 22, 313-324. [CrossRef] [PubMed]

55. Lee, J.; Jo, K.; Lim, Y.; Jeon, H.J.; Choe, J.H.; Jo, C.; Jung, S. The use of atmospheric pressure plasma as a curing process for canned ground ham. Food Chem. 2018, 240, 430-436. [CrossRef] [PubMed]

56. Albertos, I.; Martin-Diana, A.; Cullen, P.; Tiwari, B.; Ojha, S.; Bourke, P.; Álvarez, C.; Rico, D. Effects of dielectric barrier discharge (DBD) generated plasma on microbial reduction and quality parameters of fresh mackerel (Scomber scombrus) fillets. Innov. Food Sci. Emerg. Technol. 2017, 44, 117-122. [CrossRef]

57. Amini, M.; Ghoranneviss, M.; Abdijadid, S. Effect of cold plasma on crocin esters and volatile compounds of saffron. Food Chem. 2017, 235, 290-293. [CrossRef] [PubMed]

58. Yong, H.I.; Lee, S.H.; Kim, S.Y.; Park, S.; Park, J.; Choe, W.; Jo, C. Color development, physiochemical properties, and microbiological safety of pork jerky processed with atmospheric pressure plasma. Innov. Food Sci. Emerg. Technol. 2017. [CrossRef]

59. Wszelaki, A.L.; Mitcham, E.J. Effects of superatmospheric oxygen on strawberry fruit quality and decay. Postharvest Biol. Technol. 2000, 20, 125-133. [CrossRef]

60. Runguang, Z. Effect of ozone treatment on the quality of strawberry fruit during storage. Acad. Period. Farm Prod. Process. 2011, 7, 19-22.

61. Oehmigen, K.; Hähnel, M.; Brandenburg, R.; Wilke, C.; Weltmann, K.D.; von Woedtke, T. The role of acidification for antimicrobial activity of atmospheric pressure plasma in liquids. Plasma Process. Polym. 2010, 7, 250-257. [CrossRef]

62. Misra, N. Quality of cold plasma treated plant foods. Cold Plasma Food Agric. 2016, 253-271. [CrossRef]

63. Li, Y.; Kojtari, A.; Friedman, G.; Brooks, A.D.; Fridman, A.; Ji, H.-F. Decomposition of L-valine under nonthermal dielectric barrier discharge plasma. J. Phys. Chem. B 2014, 118, 1612-1620. [CrossRef] [PubMed]

64. Segat, A.; Misra, N.N.; Cullen, P.J.; Innocente, N. Effect of atmospheric pressure cold plasma (ACP) on activity and structure of alkaline phosphatase. Food Bioprod. Process. 2016, 98, 181-188. [CrossRef]

65. Attri, P.; Sarinont, T.; Kim, M.; Amano, T.; Koga, K.; Cho, A.E.; Ha Choi, E.; Shiratani, M. Influence of ionic liquid and ionic salt on protein against the reactive species generated using dielectric barrier discharge plasma. Sci. Rep. 2015, 5, 17781. [CrossRef] [PubMed]

66. Tappi, S.; Berardinelli, A.; Ragni, L.; Dalla Rosa, M.; Guarnieri, A.; Rocculi, P. Atmospheric gas plasma treatment of fresh-cut apples. Innov. Food Sci. Emerg. Technol. 2014, 21, 114-122. [CrossRef]

67. Tappi, S.; Ragni, L.; Tylewicz, U.; Romani, S.; Ramazzina, I.; Rocculi, P. Browning response of fresh-cut apples of different cultivars to cold gas plasma treatment. Innov. Food Sci. Emerg. Technol. 2017. [CrossRef]

68. Xu, Y.; Tian, Y.; Ma, R.; Liu, Q.; Zhang, J. Effect of plasma activated water on the postharvest quality of button mushrooms, Agaricus bisporus. Food Chem. 2016, 197, 436-444. [CrossRef] [PubMed]

69. Ben'ko, E.M.; Manisova, O.R.; Lunin, V.V. Effect of ozonation on the reactivity of lignocellulose substrates in enzymatic hydrolyses to sugars. Russ. J. Phys. Chem. A 2013, 87, 1108-1113. [CrossRef]

70. Dionísio, A.P.; Gomes, R.T.; Oetterer, M. Ionizing radiation effects on food vitamins: A review. Braz. Arch. Biol. Technol. 2009, 52, 1267-1278. [CrossRef]

71. Song, A.Y.; Oh, Y.J.; Kim, J.E.; Song, K.B.; Oh, D.H.; Min, S.C. Cold plasma treatment for microbial safety and preservation of fresh lettuce. Food Sci. Biotechnol. 2015, 24, 1717-1724. [CrossRef]

72. Ladikos, D.; Lougovois, V. Lipid oxidation in muscle foods: A review. Food Chem. 1990, 35, $295-314$. [CrossRef] 
73. Sarangapani, C.; Ryan Keogh, D.; Dunne, J.; Bourke, P.; Cullen, P.J. Characterisation of cold plasma treated beef and dairy lipids using spectroscopic and chromatographic methods. Food Chem. 2017, 235, 324-333. [CrossRef] [PubMed]

74. Yepez, X.V.; Keener, K.M. High-voltage atmospheric cold plasma (HVACP) hydrogenation of soybean oil without trans-fatty acids. Innov. Food Sci. Emerg. Technol. 2016, 38, 169-174. [CrossRef]

75. Shan, B.; Cai, Y.Z.; Sun, M.; Corke, H. Antioxidant capacity of 26 spice extracts and characterization of their phenolic constituents. J. Agric. Food Chem. 2005, 53, 7749-7759. [CrossRef] [PubMed] 